\title{
The Effect of Different Types of Peer Feedback Provision on EFL Students' Writing Performance
}

\section{Shirly Rizki Kusumaningrum}

$\mathrm{Ph} . \mathrm{D}$ candidate, corresponding author Graduate Program in English Language Teaching, Universitas Negeri Malang, Indonesia, shirlyrizki@gmail.com

\section{Bambang Yudi Cahyono}

Prof.,, Graduate Program in English Language Teaching, Universitas Negeri Malang, Indonesia,yudic2000@yahoo.com

\section{Johannes Ananto Prayogo}

Dr., Graduate Program in English Language Teaching, Universitas Negeri Malang, Indonesia, johannes_songky@yahoo.co.id

Writing in English is often claimed as the most complex skills compared to the other three skills. Due to its complexity, feedback is seen to be an important part in writing process since it can lead to the students' better writing performance. It has been a consensus that teacher feedback is not practical to be given in a class with a big number of students; thus, this challenges peer feedback to be implemented in the writing classroom. While there are studies showing that peer feedback is effective to enhance the students' writing performance, how peer feedback should be conducted has been overlooked and limited. In this study, we investigated the effect of two types of peer feedback provision on the students' writing performance. This study involved 55 EFL students of the English Department of a state university in Indonesia. The study revealed that both in-class peer feedback provision and small group peer feedback provisiom led to the students' better writing performance. Nonetheless, neither of these two was more effective than the other. This indicates that regardless of the types of peer feedback provision, the results will be the same.

Keywords: EFL writing classes, in-class peer feedback provision, small-group peer feedback provision, students' writing performance

\section{INTRODUCTION}

English in Indonesia is still considered as a foreign language; however, it has become a required subject to be learnt in schools (Kurniawan, 2011; Lauder, 2008; Mattarima \&

Citation: Kusumaningrum, S. R., Cahyono, B. Y. \& Prayogo, J. A. (2019). The Effect of Different Types of Peer Feedback Provision on EFL Students' Writing Performance. International Journal of Instruction, 12(1), 213-224. https://doi.org/10.29333/iji.2019.12114a 
Hamdan, 2011). Consequently, some students still have difficulties in mastering English (Suryanto, 2014). One of the skills in English that is often claimed difficult is writing, and it has been postulated that writing is a complex skill that needs some aspects to consider, such as the topic, the function of the text, and the prospective readers. Besides, as Brown (2004) argued, writing is a skill that needs to be learnt and taught to the students, especially those who learn English as a foreign language. Moreover, writing needs a very long process starting from outlining to publishing. These facts make writing even more difficult, and within Indonesian context writing is a subject that most students are reluctant to have. Hence, there should be an innovation, so that the teaching of writing would be more interesting and effective.

In line with the above-mentioned phenomena, one of the innovations in EFL writing classes that could turn the class into something more interesting and effective is the practice of peer feedback provision. Some previous researchers provided the evidence that peer feedback is substantial to enhance the students' writing performance (Berggren, 2013, 2015; Hansen \& Liu, 2005; Lundstorm \& Baker, 2009). Nonetheless, how peer feedback should be conducted has been overlooked and limited. Thus, the present study is aimed to investigate further on the implementation of different types of peer feedback provision in EFL writing classes. In other words, this study intends to see type of peer feedback provision which benefits the students in improving their writing performance.

\section{LITERATURE REVIEW}

Writing is one of the four language skills needed for communication besides listening, speaking, and reading. Compared to the three other skills, writing is believed to be the most difficult skill for EFL learners (Defazio, Jones, Tennant, \& Hook, 2010; Elander, 2006). This is because when they write, they have to consider various aspects such as the topic, the function of the text, and the prospective reader. In addition, writing contains a number of components, namely content, organization, vocabulary, language use, and mechanics (Brown, 2004; Brown, 2007). EFL learners need to be able to write well, especially in today's world in which writing is becoming more important means of communication (Harmer, 2007; Scrivener, 2011; Weigle, 2002).

Writing involves a process which starts from planning, drafting, revising, and editing before the written product is submitted. EFL learners need to be provided with feedback in the process of drafting as they are still learning to write. Ferris and Hedgcock (1998) argue that feedback is one element that remains constant in the pedagogy of writing. One of the types of feedback addresed in this research is peer feedback. The provision of feedback for peers is supported by Vygotsky's theory of Zone of Proximal Development which holds that cognitive development of individual results from social interaction (Saville-Troike, 2006). Obtaining feedback from peers is substantial in the process of writing as it can improve writing performance. Peer feedback is considered important since the students may be able to learn from their peers' writing as well (Berggren, 2013, 2015; Cho \& Cho, 2011; Cho \& MacArthur, 2011; $\mathrm{Hu}, 2005$; Lundstrom \& Baker, 2009). Thus, through peer feedback provision EFL learners can learn from each other, especially from the more proficient ones. 
A lot of literature shows that peer feedback provision is worthwhile to improve the learners' writing performance (Hansen \& Liu, 2005; Lundstorm \& Baker, 2009; Berggren, 2013, 2015). In addition, feedback makes writing more effective since it can encourage the development of EFL learners writing performance (Guenette, 2007; Montgomery \& Baker, 2007; Lee, 2008; Bitchener \& Knoch, 2010; Kamberi, 2013). Hansen and Liu (2005), for instance, suggest that students can be the source of information for each other so that they can take active roles in their own learning and they can review their ideas in light of peers' reaction. In addition, responding to peer's writing can build the critical skills that are needed to analyze and revise one's own writing. Furthermore, Lundstrom and Baker (2009) as well as Berggren (2013, 2015) conclude that learners get benefit by acting as peer reviewers since their studies revealed that the learners who provided peer feedback performed better and outperformed those who acted as receivers of the feedback. Moreover, comments from peers assist the learners to make revision on the individual's writing (Hu, 2005; Cho \& Cho, 2011; Cho \& MacArthur, 2011).

Some literature reports the benefits of training for feedback provision and involving students from the same social backgoumd. Min (2006), Lam (2010) and Rahimi (2013), for example, suggest that the students have to be trained in order to be able to provide feedback well. This is because those who had been trained to provide peer feedback had better writing performance in terms of revision types and writing quality that those who had not been trained. Nonetheless, in order to obtain the optimal result of peer feedback, the students should come from the same social background which enables them to work together; otherwise, they may not be able to maintain their social interaction due to cultural differences (Carson \& Nelson, 1996). Additionally, some have studied the students' perception on peer feedback, and the results show that peer feedback can be considered as an alternative to teacher feedback (Ghani \& Ashger, 2012; Kamberi, 2013; Miao, Badger, \& Zhen, 2006).

This study investigated the effect of peer feedback provision on the students' writing performance. We categorized feedback provision into twofold based on the number of students involved in the process of peer feedback provision. The first was in-class peer feedback provision in which any student in the class may provide feedback to the students who presented their essays in the class. The second was small group peer feedback provision in which the students were arranged in small groups so that they can provide feedback to each other. Before the students provide feedback, some explanations were given to the students so that they knew how to provide feedback to their peers either in in-class or in small group type. This study aimed to answer the following question: "Do the students who were provided with in-class peer feedback had better writing performance than those who were provided with small group peer feedback?"

\section{METHOD}

This study compared two types of peer feedback provision and see which one is more effective than the other; therefore it may be considered as a causal-comparative study (Ary et al., 2006; Creswell, 2008). This study was conducted at the English Department 
of Universitas Negeri Malang, one of the leading universities in East Java Province, Indonesia. It involved 55 fourth-semester students who attended Argumentative Writing course. These students were divided into two classes: Class A (28 students) and Class B (27 students). Students in Class A experienced the in-class peer feedback provision, while those in Class B had small group peer feedback provision.

The two types of peer feedback provision were compared to examine whether the treatment given affects the students' writing performance. Pretest and posttest were employed to gain the scores the students' writing performance before and after treatment. They were assigned to write essays in the pretest and posttest. We employed different topics for the pretest and posttest in order to avoid the 'testing effect,' The topics were Studying Overseas (for the pretest) and Online Transportation (for the posttest). The pretest scores of the two groups were analyzed by using Levene test to know whether the two groups were homogeneous. The result showed that the students were homogeneous in terms of their writing performance (see Table 1).

Table 1

Test of homogeneity of variances

\begin{tabular}{llll}
\hline Levene statistics & $\mathrm{df} 1$ & $\mathrm{df} 2$ & Sig. \\
\hline .032 & 1 & 53 & .858 \\
\hline
\end{tabular}

This study, furthermore, was conducted in 6 weeks, including the time for the pretest and posttest. There were 2 meetings in each week (see Table 2). In the treatment, the students were assigned to write three opinion essays and obtained feedback from their classmates. These 12 meetings were divided to a number of sections. The first meeting was used for the pretest. In the second meeting the students were introduced to opinion essay. In the next three meetings, the students were asked to write the first opinion essay by making an outline (the third meeting), completing the essay (the fourth meeting), and having the peer feedback (the fifth meeting). The students followed the same stages when they were asked to write the second essay (in the sixth, seventh, and eighth meetings) and the third essay (in the ninth, tenth, and eleventh meetings). The treatment was conducted in three sets to give more experiences to the students in providing and having peer feedback. The students in the two groups experienced the same stages, except when the peer feedback was provided, in-class peer feedback provision for Class A and small group peer feedback provision for Class B. The last meeting was used for posttest (the twelfth meeting). 
Table 2

Schedule for the treatment

\begin{tabular}{|c|c|c|}
\hline \multirow[b]{2}{*}{ Meeting } & \multicolumn{2}{|c|}{ Activities } \\
\hline & $\begin{array}{c}\text { Class A } \\
\text { (In-class Peer Feedback Provision) }\end{array}$ & $\begin{array}{c}\text { Class B } \\
\text { (Small Group Peer Feedback Provision) }\end{array}$ \\
\hline 1 & Pretest: & Pretest: \\
\hline 2 & $\begin{array}{l}\text { The students were introduced to the opinion } \\
\text { essay and how to write it. }\end{array}$ & $\begin{array}{l}\text { The students were introduced to the opinion } \\
\text { essay and how to write it. }\end{array}$ \\
\hline 3 & $\begin{array}{l}\text { Writing Task 1: } \\
\text { The students were asked to make an outline } \\
\text { for their first opinion essay. }\end{array}$ & $\begin{array}{l}\text { Writing Task 1: } \\
\text { The students were asked to make an outline for } \\
\text { their first opinion essay. }\end{array}$ \\
\hline 4 & $\begin{array}{l}\text { The students continued writing their opinion } \\
\text { essay }\end{array}$ & $\begin{array}{l}\text { The students continued writing their opinion } \\
\text { essay }\end{array}$ \\
\hline 5 & $\begin{array}{l}\text { The students were asked to provide in-class } \\
\text { peer feedback by presenting their friends' } \\
\text { essays in front of the class. }\end{array}$ & $\begin{array}{l}\text { The students were asked to provide peer } \\
\text { feedback by presenting their friends' essays in } \\
\text { small groups }\end{array}$ \\
\hline 6 & $\begin{array}{l}\text { Writing Task 2: } \\
\text { The students were asked to make an outline } \\
\text { for the second opinion essay. }\end{array}$ & $\begin{array}{l}\text { Writing Task } 2 \\
\text { The students were asked to make an outline for } \\
\text { the second opinion essay. }\end{array}$ \\
\hline 7 & $\begin{array}{l}\text { The students continued writing their opinion } \\
\text { essay }\end{array}$ & $\begin{array}{l}\text { The students continued writing their opinion } \\
\text { essay }\end{array}$ \\
\hline 8 & $\begin{array}{l}\text { The students were asked to provide in-class } \\
\text { peer feedback by presenting their friends' } \\
\text { essays in front of the class. }\end{array}$ & $\begin{array}{l}\text { The students were asked to provide peer } \\
\text { feedback by presenting their friends' essays in } \\
\text { small groups }\end{array}$ \\
\hline 9 & $\begin{array}{l}\text { Writing Task } 3 \text { : } \\
\text { The students were asked to make an outline } \\
\text { for the third opinion essay. }\end{array}$ & $\begin{array}{l}\text { Writing Task 3: } \\
\text { The students were asked to make an outline for } \\
\text { the third opinion essay. }\end{array}$ \\
\hline 10 & $\begin{array}{l}\text { The students continued writing their opinion } \\
\text { essay }\end{array}$ & $\begin{array}{l}\text { The students continued writing their opinion } \\
\text { essay }\end{array}$ \\
\hline 11 & $\begin{array}{l}\text { The students were asked to provide in-class } \\
\text { peer feedback by presenting their friends' } \\
\text { essays in front of the class. }\end{array}$ & $\begin{array}{l}\text { The students were asked to provide peer } \\
\text { feedback by presenting their friends' essays in } \\
\text { small groups }\end{array}$ \\
\hline 12 & Posttest: & Posttest: \\
\hline
\end{tabular}

The difference in the treatment between Class A and Class B was apparent in the way the peer feedback was provided (see Figure 1). In Class A, five students were chosen randomly to work as a group, and they were assigned to give comments on their peers' essays. They had this activity in front of the class involving the whole members of the class; hence, the activity was addressed as in-class peer feedback provision. Meanwhile, in Class B, there were 27 students and they were put in 9 different groups. In other words, there were three students within the group. 


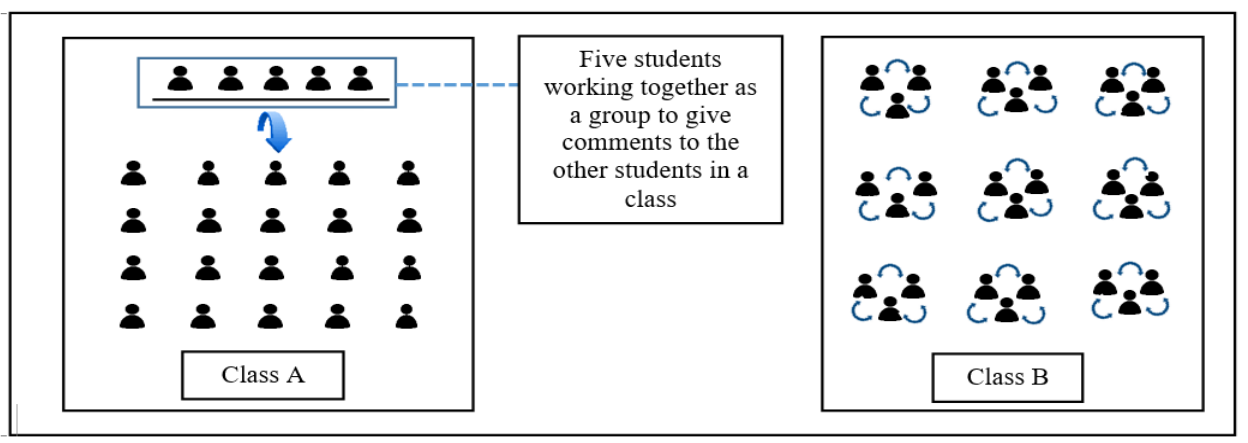

Figure 1

The way the students provided with in-class peer feedback (Class A) and small group peer feedback (Class B)

In terms of data collection, there were two sets of scores obtained from the pretest (55 essays) and the posttest (55 essays), and in order to ovoid bias and to increase the reliability (Bachman \& Palmer, 1996; Brown, 1996), the students' essays were assessed by two raters who were trained beforehand. The two raters have experienced in teaching writing for about a decade, and they have been familiar with the scoring rubric that was used to assess the students' writing in this study. The scoring rubric was adopted from Jacobs, Zingraf, Wormuth, Hartfiel, and Hughey (1981) and it covers five aspects, namely: content (30\%), organization (20\%), vocabulary (20\%), language use $(25 \%)$, and mechanics (5\%), and the scores range from poor (1), fair (2), good (3), and very good (4).

After the essays were rated by the raters, we analyzed the scores by using $t$-test for independent sample to see whether the difference of the pretest scores between the two groups was significant. The result of the analysis determined the statistical analysis for comparing of the posttest scores of the two groups.

\section{FINDINGS}

In order to reveal the effect of peer feedback on the students' writing performance, the students' pretest scores were initially compared by using descriptive statistics analysis. The result of statistical computation depicted that the mean score of Class A having inclass peer feedback provision was 71.47 with the standard deviation 6.77. Meanwhile, the mean score of Class B having small group feedback provision was 70.70 with the standard deviation 6.16 (see Table 3).

Table 3

Descriptive statistics of the pretest scores

\begin{tabular}{lccc}
\hline & $\mathrm{N}$ & Mean & Std. Deviation \\
\hline Class A & 28 & 71.47 & 6.77 \\
Class B & 27 & 70.70 & 6.16 \\
\hline
\end{tabular}


The result of comparison of the pretest scores by using independent sample $t$-test indicated that there was no significant difference $(p$ value $>.05)$ between the means of the students in Class A and those in Class B (see Table 4).

Table 4

Comparison of the pretest scores using independent sample t-test

\begin{tabular}{|c|c|c|c|c|c|c|c|c|c|c|}
\hline & \multicolumn{2}{|c|}{$\begin{array}{c}\text { Levene's Test for } \\
\text { Equality of } \\
\text { Variances } \\
\end{array}$} & \multicolumn{7}{|c|}{ t-test for Equality of Means } \\
\hline & & \multirow[t]{2}{*}{$\mathrm{F}$} & \multirow[t]{2}{*}{ Sig. } & \multirow[t]{2}{*}{$\mathrm{T}$} & \multirow[t]{2}{*}{$\mathrm{df}$} & \multirow{2}{*}{$\begin{array}{l}\text { Sig. } \\
2- \\
\text { tailed }\end{array}$} & \multirow{2}{*}{$\begin{array}{l}\text { Mean } \\
\text { Differen- } \\
\text { ce }\end{array}$} & \multirow[t]{2}{*}{$\begin{array}{l}\text { Std. Error } \\
\text { Difference }\end{array}$} & \multicolumn{2}{|c|}{$\begin{array}{l}\text { 95\% Confidence } \\
\text { Interval of the } \\
\text { Difference }\end{array}$} \\
\hline & & & & & & & & & Lower & Upper \\
\hline $\begin{array}{l}\mathrm{P} \\
\mathrm{R}\end{array}$ & $\begin{array}{l}\text { Equal variances } \\
\text { assumed }\end{array}$ & .032 & .858 & .440 & 53 & .662 & .76951 & 1.74828 & -2.73 & 4.28 \\
\hline $\mathrm{E}$ & $\begin{array}{l}\text { Equal variances } \\
\text { not assumed }\end{array}$ & & & .441 & 52.8 & .661 & .76951 & 1.74527 & -2.73 & 4.27 \\
\hline
\end{tabular}

Comparison of the posttest scores showed that the mean score of class A having in-class peer feedback provision was 75.45 with the standard deviation 10.99. Meanwhile, the mean score of class B having small group feedback provision was 76.42 with the standard deviation 8.69 (see Table 5). These data illustrated that there was an improvement on the students' writing performance.

Table 5

Descriptive statistics of the posttest scores

\begin{tabular}{lccc}
\hline & $\mathrm{N}$ & Mean & Std. Deviation \\
\hline Class A & 28 & 75.45 & 10.99 \\
Class B & 27 & 76.42 & 8.69 \\
\hline
\end{tabular}

To know the difference in the writing performance of the students, the posttest scores were compared by using independent sample $t$-test. The result indicated that there was no significant difference ( $p$ value $>.05$ ) between the means of the sores of the students in Class A and those in Class B (see Table 6). 
Table 6

Comparison of the potstest scores using independent sample t-test

\begin{tabular}{|c|c|c|c|c|c|c|c|c|c|c|}
\hline & & \multicolumn{2}{|c|}{$\begin{array}{c}\text { Levene's Test for } \\
\text { Equality of } \\
\text { Variances }\end{array}$} & \multicolumn{7}{|c|}{ t-test for Equality of Means } \\
\hline & & \multirow[t]{2}{*}{$\mathrm{F}$} & \multirow[t]{2}{*}{ Sig. } & \multirow[t]{2}{*}{$\mathrm{t}$} & \multirow[t]{2}{*}{ df } & \multirow[t]{2}{*}{$\begin{array}{l}\text { Sig. } \\
2- \\
\text { tailed }\end{array}$} & \multirow[t]{2}{*}{$\begin{array}{l}\text { Mean } \\
\text { Differen- } \\
\text { ce }\end{array}$} & \multirow[t]{2}{*}{$\begin{array}{l}\text { Std. Error } \\
\text { Difference }\end{array}$} & \multicolumn{2}{|c|}{$\begin{array}{l}95 \% \text { Confidence } \\
\text { Interval of the } \\
\text { Difference }\end{array}$} \\
\hline & & & & & & & & & Lower & Upper \\
\hline $\begin{array}{l}\mathrm{P} \\
0 \\
\mathrm{~S}\end{array}$ & $\begin{array}{l}\text { Equal } \\
\text { variances } \\
\text { assumed }\end{array}$ & .288 & .594 & $.362^{-}$ & 53 & .719 & -.970 & 2.68 & -6.34 & 4.40 \\
\hline $\mathrm{T}$ & $\begin{array}{l}\text { Equal } \\
\text { variances not } \\
\text { assumed } \\
\end{array}$ & & & .364 & 51.1 & .718 & -.970 & 2.67 & -6.33 & 4.39 \\
\hline
\end{tabular}

\section{DISCUSSION}

The results of descriptive statistics analysis depicted that the students had better writing performance after they have been exposed to either in-class peer feedback provision or small group peer feedback provision. This is in line with the findings of previous studies stating that the peer feedback benefit the students (Bitchener \& Knoch, 2010; Guenette, 2007; Lee, 2008; Montgomery \& Baker, 2007). This is because peer feedback - whether provided in-class or small group - can be categorized as collaborative learning which is derived from the social constructionist view. Within the scope of second language acquisition, this can be referred to Vygotsky's theory of Zone of Proximal Development stating that the students can learn from their peers (Saville-Troike, 2006). Such interpersonal interaction, furthermore, allowed the students to achieve better proficiency level from their peers' assistance as reflected in their final scores. Collaborating with peers, additionally, is also considered as one of the learning strategies meaning that in order to achieve certain competence in writing, the students may use this strategy.

The finding of this study was also in agreement with what has been suggested by a number of previous researchers. Bijami, Kashef, and Nejad (2013), Hansen and Liu (2005), as well as Moore and Teather (2013) have proven that students could be the source of information for other students because during the experimental condition the students actively participated in their own learning process by carefully reading their peers' writings as well as providing some fruitful comments. The findings revealed that the students gained their score after they experienced these two types of peer feedback. Class A gained 3.98 points, while class B gained 5.72 points in means. This becomes another evidence that is supported by $\mathrm{Hu}$ (2005), Cho and Cho (2011), and Cho and MacArthur (2011) since this study also revealed that the peers' comments either in- class peer feedback or small group feedback - were powerful to improve their writing performance as shown from their writing scores.

Furthermore, the implementation of in-class peer feedback provision and small group peer feedback provision allowed the students to react on their peers' essays by reading carefully and proposing idea for the betterment of their peers' essay. In other words, the 
students and their peers were active participants in their own learning; they could also reconceptualize the idea based on the feedback presented in the class. In addition, as mentioned by some experts, having peer feedback could improve the students' writing performance. The students who were trained to have peer feedback would have positive effect towards their writing since before the students gave comments on their peers' essays, they were informed on how to do the peer feedback provision, either in doing inclass peer feedback or small group peer feedback. Besides, the activities in giving the feedback were done in a number of sequences, so that the students experienced giving feedback more than once.

This study, furthermore, provides empirical evidence that the students could learn better as they provided feedback for their friends. As has been stated by Lundstorm and Baker (2009) as well as Berggren $(2013,2015)$, the students who took turn to be "reviewers" or those who learned and provided feedback for their peers' essays had better writing performance. This is logical since the students had to learn before they gave comments on their peers' writings; this led the students to actively review their previous materials which could support their writing performance. In the present study, moreover, the researchers involved the students with no various cultural differences, so that the interaction ran well, and the results could be seen from their final scores which were better than the ones they obtained in their pretest.

All in all, having the two peer feedback provision - either in-class peer feedback provision or small group peer feedback provision - offered a positive effect on the students' writing performance. The gain before and after the treatment was the evidence that confirmed the findings of a number of previous studies.

However, the result of statistical computation on the posttest scores revealed that the difference between the two groups was not significant, and there was only a slight difference on the mean scores with 0.97 ( 75.45 for in-class peer feedback provision and 76.42 for small group peer feedback provision). In conclusion, these two classes experiencing either in-class peer feedback provision or small group peer feedback provision were similar in terms of the students' writing performance.

These data lead to the conclusion that it does not matter whether peer feedback is conducted in a big group (i.e., in-class peer feedback provision) or in a small group (i.e., small group peer feedback provision), the results will turn out the same. This is because both in-class feedback and small group feedback belong to the same group, i.e., peer feedback. The difference was only about the size of the group; one involved a bigger number of the students compared to the other one. The most important finding in this study is that the teachers had less burden as it is proven that the students could also give feedback for their peers. The teacher may not need to spend extra time and energy to check the students' work. Although it cannot be denied that teacher feedback is substantial, peer feedback is proven to be effective. Consequently, peer feedback could be used as an alternative writing activity along with teacher feedback as has been revealed in the previous study (Ghani \& Ashger, 2012; Kamberi, 2013; Miao et al., 2006).

International Journal of Instruction, January2019 • Vol.12, No.1 


\section{CONCLUSION}

This study provides evidence that both in-class peer feedback provision and small group peer feedback provision led to the students' better writing performance. Nonetheless, neither in-class peer feedback nor small group peer feedback was more effective than the other. This indicates that regardless of the types of peer feedback provision, apparently the results are be the same. Then, it is suggested that English teachers put peer feedback as one of activities in the teaching of EFL writing. They may also use different types of peer feedback provision in addition to teacher feedback or any kinds of feedback provision. For the future researchers, it is expected that they can reveal some other types in peer feedback provision which can lead to the betterment of the students' writing performance.

\section{REFERENCES}

Ary, D., Jacobs, L. C., Razavieh, A., \& Sorensen, C. (2006). Introduction to research in education. Belmont: Thompson Wadsworth.

Bachman, L. F., \& Palmer, A. S. (1996). Language testing in practice: Designing and developing useful language tests. Oxford: Oxford University Press.

Bijami, M., Kashef, S. H., \& Nejad, M. S. (2013). Peer Feedback in Learning English: Advantages and Disadvantages. Journal of Studies in Education, 3(4), 91-97.

Berggren, J. (2013). Learning from giving feedback: Insights from EFL writing classrooms in a Swedish lower secondary school. Stockholm University.

Berggren, J. (2015). Learning from Giving Feedback: A study of Secondary-Level Students. ELT Journal, 69(1), 58-70.

Bitchener, J., \& Knoch, U. (2010). Raising the Linguistic Accuracy Level of Advanced L2 Writers with Written Corrective Feedback. Journal of Second Language Writing, 19(4), 207-217.

Brown, J. D. (1996). Testing in language program. New Jersey: Prentice Hall.

Brown, H.D. (2004). Language assessment: Principles and classroom practices. White Plains, NY: Pearson Education.

Brown, H.D. (2007). Teaching by principles: An interactive approach to language pedagogy. White Plains, NY: Pearson Education.

Carson, J. G., \& Nelson, G. L. (1996). Chinese Students' Perceptions of ESL Peer Response Group Interaction. Journal of Second Language Writing, 5(1), 1-9.

Cho, Y. H., \& Cho, K. (2011). Peer Reviewers Learn from Giving Comments. Inst Sci, $39,629-643$.

Cho, K., \& MacArthur, C. (2011). Learning by Reviewing. Journal of Education Psychology, 103(1), 73-84. 
Creswell, J. W. (2008). Educational research: planning, conducting, and evaluating quantitative and qualitative research. New Jersey: Persey Education.

Defazio, J., Jones, J., Tennant, F., \& Hook, S. A. (2010). Academic Literacy: The Importance and Impact of Writing across the Curriculum. Journal of the Scholarship of Teaching and Learning, 10(2), 34-47.

Ferris, D., \& Hedgcock, J. S. (1998). Teaching ESL composition: purpose, process, and practice. Mahwah, NJ: Lawrence Erlbaum.

Elander, J. (2006). Complex Skills and Academic Writing: A Review of Evidence about the Types of Learning Required to Meet Core Assessment Criteria. Assessment and Evaluation in Higher Education, 31(1).

Ghani, M., \& Asgher, T. (2012). Effects of Teacher and Peer Feedback on Students' Writing at Secondary Level. Journal of Education Research, 15 (2).

Guenette, D. (2007). Is Feedback Pedagogically Correct? Research Design Issues in Studies of Feedback on Writing. Journal of Second Language Writing, 16, 40-53.

Hansen, J. G., \& Liu, J. (2005). Guiding Principles of Effective Peer Response. ELT Journal, 59(1), 31-38.

Harmer, J. (2007). The practice of English language teaching. Essex: Pearson Education.

Hu, G. (2005). Using Peer Review with Chinese ESL students' Writers. Language Teaching Research, 9(3), 321-342.

Jacobs, H. L., Zingraf, S. A., Wormuth, D. R., Hartfiel, V. F., and Hughey, J. B. (1981). Testing ESL composition: A practical approach. Rowley, MA: Newbury House.

Kamberi, L. (2013). The Significance of Teacher Fedback in EFL Writing for Tertiary Level Foreign Language Learners. Procedia - Social and Behavioral Sciences, 70, 1686-1690.

Kurniawan, I. (2011). Indonesians' Barriers in Learning English. Journal English Education, 4(2).

Lam, R. (2010). A Peer Review Training Workshop: Coaching Students to Give and Evaluate Peer Feedback. TESL Canada Journal, 27(2), 114-127.

Lauder, A. (2008). The status and function of English in Indonesia: A review of key factors. Makara, Sosial Humaniora, 12(1), 9-20.

Lee, I. (2008). Student Reactions to Teacher Feedback in Two Hong Kong Secondary Classrooms. Journal of Second Language Writing, 17.

Lundstrom, K., \& Baker, W. (2009). To Give is Better than to Receive: The Benefits of Peer Review to the Reviewer's Own Writing. Journal of Second Language Writing, $18,30-43$. 
Mattarima, K., \& Hamdan, A. R. (2011). The Teaching Constraint of English as a Foreign Language in Indonesia: The Context of School-based Curriculum. SOCIOHUMANIKA, 4(2), 287-300.

Miao, Y., Badger, R., \& Zhen, Y. (2006). A Comparative Study of Peer and Teacher Feedback in a Chinese EFL Writing Class. Journal of Second Language Writing, 15, 179-200.

Min, H. (2006). The Effects of Trained Peer Review on EFL Students' Revision Types and Writing Quality. Journal of Second Language Writing, 15(2), 118-141.

Montgomery, J. L., \& Baker, W. (2007). Teacher-Written Feedback: Student Perceptions, Teacher Self-Assessment, and Actual Teacher Performance. Journal of Second Language Writing, 16, 82-99.

Moore, C., \& Teather, S. (2013). Engaging Students in Peer Review: Feedback as Learning. Issues in Educational Research, 23(2), 196-211.

Rahimi, M. (2013). Is Training Students Reviewers Worth Its While? A study of How Training Influences the Quality of Students' Feedback and Writing, Language Teaching Research, 17(1), 67-89.

Saville-Troike, M. (2006). Introducing second language acquisition. Cambridge: Cambridge University Press.

Scrivener, J. (2011). Learning teaching: The essential guide to English language teaching. London: Macmillan.

Suryanto. (2014). Issues in Teaching English in a Cultural Context: A Case of Indonesia. The Journal of English Literacy Education, 1(2), 1-11.

Weigle, S. C. (2002). Assessing writing. Cambridge: Cambridge University Press. 